\title{
Intersectionality and disability in international human rights law
}

\begin{abstract}
:
This article addresses the question of intersectionality in the field of international human rights law. While in this field much attention has been given to gender and race, here it is extended to disability. Starting from the Convention on the Rights of Persons with Disabilities (CRPD), the article explores a new as yet unexplored research avenue: how international human rights law can protect different groups of disabled people by applying the Convention along with other human rights treaties. It focuses on three groups of disabled people: 1) disabled people belonging to racial or ethnic minorities; 2) disabled women and; 3) disabled children. These three groups have been chosen because all three come within the remit of human rights treaties that concern these groups in addition to the CRPD. Some other groups of disabled people are also considered. The article discusses the problems that emerge for these groups and shows how they can be resolved through international human rights law. This is done through an analysis of the jurisprudence of UN treaty bodies.
\end{abstract}

Keywords: Intersectionality, International human rights law, Disability, Human rights treaties, Particular groups of disabled people 


\section{Introduction}

Intersectional discrimination refers to a situation in which people are discriminated against on different grounds which, taken together, result in a level of prejudice that is higher than if these different grounds were taken separately. Coined by Kimberley Crenshaw with regard to gender and race, ${ }^{1}$ it means that when they intersect both gender and race can create specific disadvantages that are greater than the sum of their parts. ${ }^{2}$ This contrasts with additive discrimination, where the grounds can in fact be broken down and taken separately. Both intersectional discrimination and additive discrimination can be seen as different kinds of multiple discrimination.

Research into intersectionality is only slowly emerging in the field of international human rights law. Scholars have pointed out the necessity of recognising women's heterogeneity in the protection of human rights in relation to race, ${ }^{3}$ and in combination with migration. ${ }^{4}$ More recently, others approached the question of intersectionality in a broader fashion through the prism of international human rights law. A special issue of the The Equal Rights Review examined its potential as a conceptual tool in the international framework of human rights. Ivona Truscan and Joanna Bourke-Martignon assessed how far the UN treaty bodies have considered intersectionality in their general comments and concluding observations. ${ }^{5}$ Johanne Bouchard and Patrice Meyer-Bisch examined its capacity to handle complex situations of human rights violations. ${ }^{6}$ Ben Smith likewise pleaded to move beyond the intersection of gender and race to acknowledge the multiple experiences of oppression. ${ }^{7}$ Elsewhere, Pok Yin Chow exposed the limits of intersectionality in the way the UN treaty bodies have handled identities in conflict in relation to cultural and religious practices. ${ }^{8}$

This article addresses the question of intersectionality with regard to a particular ground of discrimination that has attracted little attention to date, namely disability. Several scholars 
have considered how this ground intersects with other grounds of discrimination in the wake of the Convention on the Rights of Persons with Disabilities (CRPD) adopted in 2006. In a seminal report drafted for the UN before the CRPD had been adopted, Gerard Quinn and Theresia Degener analysed the applicability of human rights treaties to disability and the desirability of adopting a new binding international legal instrument. ${ }^{9}$ Theresia Degener subsequently studied how far consideration for intersectionality has progressed within the international human rights framework, observing how limited was the attention paid to disability by the UN treaty bodies. ${ }^{10}$ Aart Hendriks similarly noted this lack of consideration in human rights treaties generally. ${ }^{11}$ Oddný Arnardóttir demonstrated how recent attention to disability generated a shift in focus from immovable discrimination grounds to an understanding of disadvantage as multi-dimensional. ${ }^{12}$ Gauthier de Beco examined how with the adoption of an intersectional perspective disability could be better anchored in the field of international human rights law. ${ }^{13}$

The article takes this research further by inquiring into the use of international human rights law with a view to protecting different groups of disabled people. ${ }^{14}$ Building upon Oddný Arnardóttir's approach to multidimensional disadvantage and Theresia Degener's view of intersectionality from the perspective of disability, it researches how human rights treaties actually operate when disability and other grounds of discrimination intersect. It does so not by dwelling on these discrimination grounds, which would be necessary for establishing instances of intersectional discrimination and which has been the main approach up until now, but by proceeding to evaluate intersecting forms of disadvantage faced by particular groups of disabled people who share characteristics that also belong to other marginalised groups of people. $^{15}$

This article thus focuses on problems that emerge for those possessing distinctive personal features within the overall group of disabled people, which are resolved through international 
human rights law. Such an approach considers how disabled people are treated across human rights treaties. Just as was done by Gerard Quinn and Theresia Degener, the article applies these human rights treaties, but this time by starting from the CRPD thirteen years after it was adopted. It thus follows Rangita de Silva de Alwis' suggestion that disabled women and children 'are best protected when the CRPD is read together with the panoply of guarantees set out in other human rights treaties'. ${ }^{16}$ This requires not only understanding the heightened level of prejudice that arises when disability intersects with other grounds of discrimination but also applying the CRPD along with these human rights treaties in order to respond to the specific situation of the different groups of disabled people. Such an inquiry allows not only the exploration of power relations beyond vested identities, ${ }^{17}$ but is also in line with international human rights law itself, which includes a series of human rights treaties for particular marginalised groups of people besides those human rights treaties that are universal.

Three groups of disabled people are here under consideration: 1) disabled persons belonging to racial or ethnic minorities; 2) disabled women; and 3) disabled children. These three groups were chosen because all three come within the remit of human rights treaties that concern these groups in addition to the CRPD. Other groups of disabled people are also considered in this article, that is, those who either belong to more than one of the three groups or have no human rights treaty that applies to them specifically other than this Convention.

The article relies not only on academic scholarship but also on the UN treaty bodies' general comments and concluding observations insofar as they focus on the aforementioned groups of disabled people. It also refers to relevant reports by NGOs and UN agencies. The purpose is to offer evidence on how disability can be made to be race-, gender- and agerelated and so on and to determine what international human rights law can offer those groups of disabled people. The article both compares the provisions of human rights treaties and analyses their interpretation by the respective UN treaty bodies. It shows not only how far 
these treaty bodies pay attention to the different groups of disabled people but also highlights where there remains a lack of guidance on how to protect them.

Finally, this article is divided into two parts. Following the introduction, it starts with a discussion of intersectionality with special attention given to disability. It goes on to make an investigation of human rights protection for the aforementioned groups of disabled people by applying the CRPD along with other human rights treaties.

\section{Intersectionality and the CRPD}

The International Covenant on Civil and Political Rights (ICCPR) and International Covenant on Economic, Social and Cultural Rights (ICESCR) were joined successively by a number of human rights treaties for particular marginalised groups of people: the International Convention on the Elimination of All Forms of Racial Discrimination (ICERD); the Convention on the Elimination of All Forms of Discrimination against Women (CEDAW); and the Convention on the Rights of the Child (CRC). Each has its own treaty body: the UN Human Rights Committee (HRC); the UN Committee on Economic, Social and Cultural Rights (CESCR Committee); the UN Committee on the Elimination of Racial Discrimination (CERD Committee); the UN Committee on the Elimination of All Forms of Discrimination against Women (CEDAW Committee); and the UN Committee on the Rights of the Child (CRC Committee).

Thus, international human rights law has evolved in the direction of adopting groupspecific human rights treaties following the adoption of the ICCPR and ICESCR. While these human rights treaties were drafted with particular categories in mind, those who belong to more than one category have often received limited consideration. An unwanted consequence of international human rights law, therefore, is that a number of historically marginalised 
groups of people are getting particular attention but without full consideration for those who also share characteristics that belong to several such marginalised groups of people.

While the problem is inherent to the development of international human rights law, it is important to ensure that the interpretation of human rights treaties remains coherent and to undertake efforts of harmonisation towards this end. ${ }^{18}$ The fact that there are people who simultaneously come within the remit of different group-specific human rights treaties creates the necessity of building bridges between the various categories. Although the UN treaty bodies have given these people some consideration, they have done so unequally. ${ }^{19}$ There is a tendency to concentrate on monolithic identities, thereby downplaying the multiple characteristics of individuals. Categories are mainly formed on the basis of the life experience of a group's most dominant members, disregarding that of the group's more disadvantaged ones. ${ }^{20} \mathrm{~A}$ focus on monolithic identities, however, obscures the differences and even possible struggles between the members of such a group. Intersectionality can help to recognise that individuals are actually not constituted by any single essence.

Prior to the CRPD, only some of the UN treaty bodies paid attention to disability. The CRC Committee is the one that went furthest in doing so, but this is partly due to the CRC itself focusing on disability. The Convention was indeed the first human rights treaty ever to do so, not only by referring explicitly to disability amongst the grounds listed in its nondiscrimination clause but also by including a full article on disabled children. ${ }^{21}$ The CRC Committee, therefore, had to pay attention to disability. It adopted a general comment on disabled children, which provides a detailed examination of matters specifically relating to them. ${ }^{22}$ The CESCR Committee also issued a general comment on disabled people, ${ }^{23}$ in which it clarified that disability is covered by the term 'other status' in the ICESCR's nondiscrimination clause, ${ }^{24}$ clarification which the HRC has failed to follow up on with respect to the ICCPR's own non-discrimination clause. The CEDAW Committee similarly adopted a 
general comment on disabled women. ${ }^{25}$ Several UN treaty bodies have also made a number of recommendations on disability-related issues in their concluding observations. The number of these recommendations has steadily grown following the adoption of the CRPD, even though there are still significant variations amongst them. ${ }^{26}$

The CRPD itself was preceded by a series of non-binding international legal instruments that gradually shaped its content. ${ }^{27}$ It was adopted on 13 December 2006 after four years of negotiations initiated by the Mexican government. ${ }^{28}$ The UN Committee on the Rights of Persons with Disabilities (CRPD Committee) was created to monitor its implementation. The CRPD fills an important normative gap in international human rights law, as disabled people were disregarded in previous human rights treaties (with the exception of the CRC). By July 2019, there were 162 signatories and 179 parties to the Convention. ${ }^{29}$

In comparison with other human rights treaties, the CRPD stands out for its consideration of intersectionality. According to its Preamble, States Parties are

[c]oncerned about the difficult conditions faced by persons with disabilities who are subject to multiple or aggravated forms of discrimination on the basis of race, colour, sex, language, religion, political or other opinion, national, ethnic, indigenous or social origin, property, birth, age or other status.

This provision is the first such one ever to be found in a human rights treaty. The CRPD further prohibits discrimination against disabled people 'on all grounds' ${ }^{30}$ As set out below, the CRPD moreover deals with particular groups of disabled people. Besides provisions that refer explicitly to gender and age, it has full articles on disabled women and children. The CRPD Committee has also issued a general comment regarding disabled women and girls. ${ }^{31}$ It 
even paid further attention to such groups in a recent general comment on equality and nondiscrimination. $^{32}$

Finally, the CRPD is the most recent group-specific human rights treaty there is. As its drafters found inspiration in previous human rights treaties, this Convention generally contains the most developed and updated provisions on human rights to date. It therefore provides a promising opportunity for examining the question of intersectionality in the field of international human rights law.

\section{Human rights protection for particular groups of disabled people}

This section focuses on a number of groups of disabled people who share characteristics that also belong to other marginalised groups of people. It discusses first of all three such groups who come within the remit of group-specific human rights treaties other than the CRPD (which it does in the chronological order in which these human rights treaties were enacted): 1) disabled people belonging to racial or ethnic minorities; 2) disabled women and; 3) disabled children. It goes on to look at some other groups which either straddle these three groups or have no human rights treaty that specifically apply to them other than this Convention. While the focus is on human rights treaties for particular marginalised groups of people, attention is paid to both the ICCPR and the ICESCR. Non-binding international legal instruments are also taken into account.

\section{Disabled people belonging to racial or ethnic minorities}

Disabled people belonging to racial or ethnic minorities are especially disadvantaged in modern societies. Their cultural and linguistic characteristics lead to both stigma and 
stereotyping that compound their disability. ${ }^{33}$ They experience severe difficulties both in finding employment and in accessing healthcare services. ${ }^{34}$ Racial discrimination is increased because of poorer communication skills and because of lower socio-economic status. In addition, they tend to be assigned mental disabilities. They are mistakenly diagnosed, and therefore may also suffer discrimination on the basis of disability. ${ }^{35}$ Such forms of prejudice result from the intersection of race and disability, since they are related to both of them at the same time.

Disabled people from racial or ethnic minorities may have a migrant background. However, migrant disabled people are generally neglected when it comes to policy making. Not only is there limited data on them, but often they may not be identified as disabled when they enter the host country. ${ }^{36}$ The problem is that disability sometimes undermines their immigration prospects, and is therefore less likely to be disclosed by them. Migrant disabled people may also have no social protection in their host country unless they hold a permanent residency permit. ${ }^{37}$ As a result, they have no access to the healthcare services they require in order to be able to live adequately.

Examples include a blind Turkish woman in the Netherlands who asked for a test in Braille in order to determine her position in an organisation. The oral examination was particularly difficult for her, as her first language was not Dutch, but the request was denied. The Dutch Equal Treatment Commission (now the Netherlands Institute for Human Rights) considered that she was discriminated against due to the intersection of race and disability. ${ }^{38} \mathrm{~A}$ related example is migrant deaf people who were used to speaking in the sign language of their country of origin and who now have to acquire new communication skills such as lipreading. ${ }^{39}$ Their migrant background creates challenges that give extra weight to their disability. 
The question is how to resolve such problems with the aid of international human rights law. Taking a step back is necessary in order to examine how the different grounds in intersection can be worked out through the application of human rights treaties. Disabled people belonging to racial or ethnic minorities come within the remit of the CRPD and ICERD, but these human rights treaties approach them differently.

The CRPD devotes little attention to disabled people from racial or ethnic minorities. While multiculturalism and migration have become central issues in human rights debates, the Convention includes no specific provisions on issues related to race. Only in the Preamble does it make any mention of race and ethnic origin. ${ }^{40}$ The CRPD Committee has occasionally referred to race in relation to multiple discrimination. ${ }^{41}$ It placed greater focus on migrant disabled people. For instance, it recommended that the United Arab Emirates ensures that '[d]etention and deportation centres are accessible to migrant workers with disabilities', that Portugal supports those who are 'in situations of destitution or extreme poverty', and that Germany ensures that 'programmes for migrant populations in the State party are fully accessible for persons with disabilities'. ${ }^{42}$ Considering the global migration crisis, it recommended that 'States parties that receive a high number of asylum seekers, refugees or migrants should put in place formal, legally defined procedures to ensure accessibility for persons with disabilities'. ${ }^{43}$ Also worth mentioning is the International Convention on the Protection of the Rights of All Migrant Workers and Members of Their Families (CMW). While the CMW has not been ratified by most so-called 'migrant-receiving countries, the Committee on the Protection of the Rights of All Migrant Workers and Members of their Families (CMW) and the CRPD Committee issued a 'Joint Statement' wherein they highlighted the lack of consideration for migrant disabled people. ${ }^{44}$

The ICERD is the oldest human rights treaty; it was adopted even before the ICCPR and the ICESCR. It is almost exclusively concerned with non-discrimination. The CERD 
Committee has adopted a general comment on the gendered dimension of race. ${ }^{45}$ Although it did not adopt any general comment focusing on disability, this general comment can be read by analogy as applying to those who are disabled. ${ }^{46}$ More guidance on how to protect disabled people belonging to racial or ethnic minorities is as yet unavailable. The question remains whether applying both the ICERD and the CRPD could help obtain such guidance.

The CRPD makes provision for equal conditions of recruitment, hiring and employment. ${ }^{47}$ It also requires that disabled people be able to access healthcare services, which should be as close as possible to their own communities. ${ }^{48}$ The Convention, however, gives no consideration to the intersection of race and disability (except in the Preamble). This was evident when the CRPD Committee received a complaint from an Aboriginal Australian who was declared 'unfit to plead'. ${ }^{49}$ Although it considered that such a practice was in violation of the Convention, it failed to consider his indigenous origins.

The question is whether non-binding international legal instruments could be read to consider the race-related dimension of disability. While the ICERD does not offer any provisions towards this end, the Durban Declaration and Programme of Action (DDPA) ${ }^{50}$ includes a commitment to improve the prospects of vulnerable groups and refers several times to those who are subject to 'multiple discrimination'. ${ }^{51}$ Aware of how race intersects with disability, it encouraged stakeholders 'to address the situation of persons with disabilities who are subject to racism'. ${ }^{52}$ The DDPA, however, does not make any further references to disability. Besides the CMW, the ICCPR and ICESCR are still relevant, as both of them provide an entry point for considering the intersection of race and disability thanks to their non-exhaustive list of discrimination grounds. While it was noted that the two covenants were not much relied upon with regard to disability before the adoption of the CRPD ${ }^{53}$ their usefulness could nevertheless be further examined in this regard and their universality explicitly extended to disabled people from racial or ethnic minorities. 
International human rights law provides limited protection to disabled people belonging to racial or ethnic minorities. The latter fall under the remit of the oldest and newest groupcategory specific human rights treaties, namely the ICERD and CRPD, respectively. While the former did not have them in mind when it was drafted, the latter limits itself to a reference to race and ethnic origin in its Preamble. The CRPD Committee only considered the issue through the prohibition of discrimination, although it paid special attention to migrant disabled people. The DDPA has given disabled people belonging to racial or ethnic minorities some, albeit sporadic, consideration, but both the ICCPR and the ICESCR may have the potential to provide a stronger basis in order to enhance human rights protection for them.

\section{Disabled women}

Disabled women are frequent victims of human rights violations. Facing negative attitudes and social rejection, they experience a high level of prejudice in comparison with both disabled people and women. ${ }^{54}$ This includes both domestic violence by family members and sexual abuse in residential homes by caregivers. ${ }^{55}$ There is at the same time a general belief that disabled women have no sexual life and that they are unsuited to motherhood, the result being that their children are frequently taken away from them in the case of separation or divorce ${ }^{56}$ Disabled women are thus considered as both asexual and hyper-sexual. The fact that such opposite sexual features are attributed to them is testament to the particular way in which gender and disability intersect.

A case in point is the forced sterilisation of disabled women, which is done in order to prevent pregnancy. ${ }^{57}$ Such sterilisation affects those who are intellectually disabled in particular. ${ }^{58}$ An equivalent is the strong encouragement to accept, or even be subjected to, forced abortion. Also related to this is limited access both to sexual and reproductive 
healthcare services and to information on sexual and reproductive rights. ${ }^{59}$ In a similar vein, prenatal, delivery and post-natal care are usually unavailable to disabled women or ill-adapted to their needs. ${ }^{60}$

The question is what international human rights law requires to combat such practices. This involves an examination of how different human rights treaties deal with disabled women. The latter fall under the remit of the CRPD and CEDAW, which approach them in different ways.

The CRPD devotes much attention to disabled women. It includes a full article on disabled women, which even mentions that they are subject to 'multiple discrimination'. ${ }^{61}$ This is the strongest provision on intersectionality in this Convention - and indeed ever in any human rights treaty. Furthermore, the CRPD deals with gender-related issues in many other provisions. ${ }^{62}$ The Preamble further stresses the need to incorporate a 'gender perspective' into the entire Convention. ${ }^{63}$ There is thus a 'twin-track' approach to the issue of gender in the CRPD, with both a full article on disabled women and several provisions taking into account gender. Unable to choose between either option, the drafters eventually opted for both. ${ }^{64}$ The CRPD has adopted a general comment on disabled women and girls, in which it reckoned that 'individuals do not experience discrimination as members of a homogeneous group'. ${ }^{65}$ It also considered that disabled women are 'among those groups of persons with disabilities who most often experience multiple and intersectional discrimination' ${ }^{66}$

The CEDAW aims to put an end to discrimination against women. A criticism though has been that it concentrates largely on male-related issues and emphasises above all the public sphere. ${ }^{67}$ The problem was to a certain extent remedied with the adoption of the Declaration on the Elimination of Violence against Women (DEVAW). ${ }^{68}$ The CEDAW also tends to consider women a homogenous category, ignoring those who possess distinctive personal features within the overall group of women with the only exception of those living 'in rural 
areas'. ${ }^{69}$ Its non-discrimination clause is restricted to 'sex' ${ }^{70}$ In the Beijing Declaration and Platform for Action (BPfA), ${ }^{71}$ there is nonetheless a commitment to promote the rights of 'women and girls who face multiple barriers ... because of such factors as ... disability' ${ }^{72}$

The lack of consideration for disability has somewhat been neutralised by the CEDAW Committee. The latter is probably the treaty body that has gone farthest in dealing with intersectionality. It issued a number of general recommendations on particular groups of women, the first of which was precisely on those who are disabled. ${ }^{73}$ While the CEDAW Committee did so chiefly with the purpose of asking States Parties to submit information on disabled women in their State reports, it expressed its concern about the fact that disabled women 'suffer from a double discrimination linked to their special living conditions'. ${ }^{74}$ In its general comment on temporary general measures, it recognised that women 'may also suffer from multiple forms of discrimination based on additional grounds such as ... disability' ${ }^{75}$ It also referred to 'intersectionality' in relation to core obligations and highlighted the right to health of disabled women. ${ }^{76}$ The CEDAW Committee paid greater attention to disabled women in its concluding observations after the CRPD's adoption, although it did not always dealt with matters specifically relating to them. ${ }^{77}$ It furthermore handled several cases of intersectional discrimination, ${ }^{78}$ including one where it considered that the absence of sign language for a deaf woman in legal proceedings amounted to a violation of the CEDAW. ${ }^{79}$ The CESCR Committee likewise issued a general comment on disabled people, in which it has gone further than the CEDAW Committee. It recognised that disabled women may suffer from 'double discrimination' and addressed their reproductive rights and parenthood in particular. ${ }^{80}$ The next step involves the application of the CRPD along with the CEDAW as well as other international legal instruments to determine what must be done in order to protect these women. 
The CRPD stipulates that States Parties must protect disabled people against 'all forms of exploitation, violence and abuse, including their gender-based aspects', and prevent such 'forms of exploitation, violence and abuse by ensuring ... appropriate forms of gender- ... sensitive assistance [and] protection services ... [that] are gender- ... sensitive' ${ }^{81}$ While the CEDAW Committee has not addressed such issues, DEVAW provides for measures to eliminate acts of violence against women. ${ }^{82}$ The application of the CRPD along with the CEDAW in addition to DEVAW can help unpack the gender-related dimension of disability. Relevant steps could be the prevention, investigation and punishment of exploitation, violence and abuse against disabled women. They also involve training to understand the underlying causes and reduce their occurrence. Certain measures set out in the CEDAW - and especially DEVAW - could also be used to combat acts of violence that occur within the private sphere. Such acts of violence include sexual abuse in residential homes, which concern especially disabled women.

Regarding forced sterilisation, the CRPD provides for disabled people's right to 'retain their fertility on an equal basis with others' ${ }^{83}$ The CRPD Committee specified that 'women with disabilities have the right to found a family and be provided with appropriate assistance to raise their children' ${ }^{84}$ It thereby followed the Human Rights Committee, which stressed that ' $[\mathrm{t}]$ he right to found a family implies, in principle, the possibility to procreate and live together' ${ }^{85}$ The CRPD moreover stipulates that healthcare should be provided to disabled people 'on the basis of free and informed consent'. ${ }^{86}$ This consent, therefore, is a condition before any form of medical treatment is possible. Although the CEDAW itself does not refer to disability, the CEDAW Committee has recommended to Australia, for instance, that the State Party '[enacts] national legislation prohibiting ... the use of sterilisation of girls, regardless of whether they have a disability. ${ }^{87}$ The CESCR Committee likewise considered 
that the sterilisation of 'a woman with disabilities without her prior informed consent' violates her right to protection of the family. ${ }^{88}$

The CRPD grants extensive sexual and reproductive rights to disabled women. It provides that these women must have access to healthcare services 'including in the area of sexual and reproductive health' as well as access to 'reproductive and family planning education'. ${ }^{89}$ Recognising that ' $[\mathrm{w}]$ omen with disabilities ... often have difficulty with physical access to health services', the CEDAW Committee too advised that States Parties take measures to 'ensure that health services are sensitive to the needs of women with disabilities' ${ }^{90}$ It has recommended to Jamaica, for instance, that the State Party 'promote ... access to services, including mental, sexual and reproductive health services'. ${ }^{91}$

As can be seen from the above analysis, disabled women are well served by international human rights law. The CRPD by itself pays much attention to them through its 'twin-track' approach to the issue of gender. This confirms that these women were already taken into consideration prior to the Convention. Gender mainstreaming has been taking place for several decades throughout the UN, which influenced the negotiation process. The CEDAW does not focus on particular groups of women, but this has been compensated both by the CEDAW Committee' general recommendations and concluding observations and by nonbinding international legal instruments. Thus, while the CRPD extensively deals with issues related to gender, those general recommendations and concluding observations allow for certain provisions in the CRPD to be refined and the gender-related dimension of disability to be brought to the fore. The conclusion is that the application of both human rights treaties can bear fruit for disabled women. 


\section{Disabled children}

Disabled children are very much excluded from society, being especially surrounded by negative stereotypes. ${ }^{92}$ Their vulnerability due to childhood gets aggravated through another layer of prejudice, which depicts them as inferior compared to other children. They are victims of many forms of violence as well as punishment in order to modify their behaviour. ${ }^{93}$ Disabled children are regularly taken away from their families and placed in institutions where they are often mistreated. ${ }^{94}$ Their families also face great hardship, because these children are particularly dependent on them. ${ }^{95}$ As a result of increased care responsibilities, parents may experience difficulties in coping with their own life and suffer breakdowns. ${ }^{96}$ They can themselves be subject to discrimination on the basis of disability, a phenomenon called discrimination by association.

A notable example is the lack of education for disabled children. In many parts of the world, these children simply cannot go to school. ${ }^{97}$ In Western countries, they are often referred to so-called 'special schools', which provide lower standards of education. ${ }^{98}$ The problem is that infrastructures are generally not accessible to disabled children, as they have been developed without them in mind and as they do not offer them the support they need. ${ }^{99}$ They are given no place in the general education system, because their presence is seen as too burdensome. ${ }^{100}$ While the education system can exert pressure on certain groups of pupils, it often goes to extremes with those who are disabled. A related issue is the frequent referral to 'special schools' of children belonging to racial or ethnic minorities (which will be discussed later).

The question is how international human rights law gets to grips with such problems. The answer may be found by applying the relevant human rights treaties. Disabled children come within the remit of the CRPD and CRC, both of which have different approaches to them. 
The CRPD gives particular attention to disabled children. As with disabled women, it contains a full article on disabled children (which, however, makes no reference to 'multiple discrimination'). ${ }^{101}$ The CRPD also has a number of provisions on issues related to age. ${ }^{102}$ In addition, Article 24 protects the right to inclusive education, which especially concerns those who are in childhood and on which the CRPD Committee has issued a general comment. ${ }^{103}$ Once again, the CRPD shows a 'twin-track' approach to the issue of childhood, that is, a full article on disabled children as well as provisions taking age into account. In its general comment on equality and non-discrimination, the CRPD Committee also advised States Parties to 'promote the mainstreaming of disability in general laws and policies on childhood'. ${ }^{104}$

The CRC proclaims a wide range of children's rights. It consists of four general principles, which were established by the CRC Committee and which were incorporated into the CRPD. ${ }^{105}$ The CRC's non-discrimination clause has a non-exhaustive list of discrimination grounds that refers explicitly to 'disability'. ${ }^{106}$ Like the CRPD, the CRC has a full article on disabled children. ${ }^{107}$ This article is even more detailed than its equivalent in the CRPD. ${ }^{108}$ The latter was nearly left out by the drafters for the sake of consistency. ${ }^{109}$ The CRC has nonetheless some drawbacks, such as its focus on 'special care' for disabled children, which should be 'subject to available resources ... appropriate to the child's condition' and for which 'assistance ... shall be provided free of charge, whenever possible'. ${ }^{110}$ Such wording implies that disability remains a question of welfare. The CRC Committee has also been very sensitive to issues related to disability in its work. ${ }^{111}$ It supported the adoption of the new human rights treaty in its general comment on disabled children (which was issued soon after the CRPD was adopted). ${ }^{112}$ As a result, there is potential synergy to be established between the two human rights treaties. 
The CRC Committee has given great attention to intersectionality. It has emphasised the need to address 'the implications of multiple forms of discrimination' with regard to the right to health. ${ }^{113}$ It reminded States Parties of the Convention's non-exhaustive list of discrimination grounds in several general comments, ${ }^{114}$ and considered the question of intersectionality in many concluding observations. ${ }^{115}$ The CRC Committee has also drafted a general comment jointly with the CEDAW Committee (a pioneering initiative in the field of international human rights law). Both treaty bodies recognised that 'harmful practices' reflect stereotypes towards 'certain disadvantaged groups of women and children, including individuals with disabilities and albinism'. ${ }^{116}$

After issuing its general comment on disabled children, the CRPD Committee has moved slowly but surely from a medical model to a social model of disability while making more recommendations on matters specifically relating to disabled children. ${ }^{117}$ It continued to focus on disabled children in its subsequent general comments. ${ }^{118}$ UNICEF has also written two reports on disabled children, in which it made broad use of the CRPD. ${ }^{119}$ The question now is whether applying both human rights treaties - the CRPD and the CRC - provides direction on how to protect such children.

The CRPD stipulates that States Parties must 'prevent all forms of exploitation, violence and abuse ... [through] age-sensitive assistance'. ${ }^{120}$ This is echoed in the CRC. ${ }^{121}$ The two human rights treaties require not only the provision of support but also identification, investigation and follow-up. ${ }^{122}$ The CRC Committee has also recommended training and education as well as monitoring and sanctions. ${ }^{123}$ Recognising that ' $[\mathrm{c}]$ hildren with disabilities are especially vulnerable to exploitation, abuse and neglect', the CESCR Committee also considered that they must be 'entitled to special protection'. ${ }^{124}$ The CRPD Committee reckons that 'States parties should address violence and institutionalization of children with disabilities, who are denied the right to grow up in their families'. ${ }^{125}$ Both the CRC and the 
CRPD provide - in similar terms - that 'a child shall not be separated from his or her parents against their will' ${ }^{126}$ The CRC further specifies that 'children of working parents have the right to benefit from child-care services for which they are eligible'. ${ }^{127}$ As indicated by the CRC Committee in its general comment on disabled children, such 'services should ... include different forms of respite care, such as care assistance in the home and day-care facilities'. ${ }^{128}$ This stresses the important role of families in advancing the rights of disabled children. $^{129}$

When it comes to education, the CRPD requires that States Parties 'ensure an inclusive education system at all levels'. ${ }^{130}$ They must guarantee that disabled children are able to 'access an inclusive, quality and free primary education and secondary education' and that disabled people 'receive the support required, within the general education system, to facilitate their effective education' ${ }^{131}$ Inclusive education is a new issue that was introduced by the CRPD. ${ }^{132}$ Its novelty perhaps explains why the CRC Committee has been somewhat ambiguous on this issue in its own general comment on disabled children. ${ }^{133}$ The CRPD Committee has clarified this ambiguity in a general comment on the right to inclusive education, in which it has defined the 'core features of inclusive education'. ${ }^{134}$ Yet, the CRC requires that disabled children be educated 'in a manner conducive to the child's achieving the fullest possible social integration'. ${ }^{135}$ This underlines the fact that the provision of education should contribute to their formation as future adults, thus unpacking the age-related dimension of disability.

Disabled children fall under the remit of two group-specific human rights treaties that give them a lot of consideration. The CRPD has a 'twin-track' approach to the issue of age, while the CRC focuses on disability. Following the CRPD's adoption, the CRC Committee became even more attentive to the particular needs of disabled children. Other organisations have also shown increased awareness of the intersection of age and disability. Like disabled women, 
disabled children, therefore, have a lot to gain from international human rights law. While both the CRPD and the CRC deal with them, they do so from different perspectives. On the one hand, the CRC is generally concerned with childhood, focusing on the provision of welfare and reliance on family and social relationships. On the other hand, the CRRD is principally concerned with disability, aiming at full inclusion into society and the promotion of autonomy. Even though the latter is more advanced than the former with regard to disabled children, there is an added-value in applying both human rights treaties in order to know how to protect them.

\section{Other groups}

There are groups that overlap among the three groups of disabled people examined above. These groups experience specific disadvantages that result from the intersection of disability with several other grounds of discrimination. It is therefore worth examining how international human rights law applies to these groups too. Such an examination may show how particular groups of disabled people are protected when they come within the remit of more than one group-specific human rights treaty other than the CRPD.

One such particular group is disabled children belonging to racial or ethnic minorities. The problem is not only their social status but also their linguistic and cultural characteristics which are not adequately taken into account. ${ }^{136}$ It also concerns children from racial or ethnic minorities who more often than other children are labelled as disabled and who are likely to suffer from similar kinds of prejudice. ${ }^{137}$ Children belonging to racial or ethnic minorities, therefore, can suffer from exclusion due to the intersection of race as well as age and disability. The intersection of gender can be added here, given that boys are much more frequently affected by this type of exclusion than girls. ${ }^{138}$ 
Roma children in Eastern Europe, for instance, are often referred to 'special schools' on the basis of biased capacity assessments. ${ }^{139}$ While these 'special schools' are reserved for disabled children, other motives underlie their segregation. As a result, Roma children tend to be overrepresented in these 'special schools'. ${ }^{140}$ The European Court of Human Rights has ruled that such practice constitutes racial discrimination in several cases including the case of $\mathrm{DH}$ and others $v$ Czech Republic. ${ }^{141}$ However, the problem is also related to disability. The segregation of Roma children is a matter of intersectionality, because it is the interconnection of both race and disability that makes this segregation possible. There is a double problem: a segregated education system and unjustified rejection measures.

The question is what international human rights law provides in order to resolve these problems. This requires applying several group-specific human rights treaties. Three of them are relevant in the present case, namely the CRPD, ICERD and the CRC.

The CRPD protects the right of disabled people to education. ${ }^{142}$ While it mentions race and ethnic origin in the Preamble, ${ }^{143}$ it has no provisions on issues related to race. In its general comment on the right to inclusive education, the CRPD Committee stated that all children must be 'welcomed equally, with respect for diversity according to, inter alia, disability, race, ... or other status' and recognised that disabled people 'can experience intersectional discrimination based on disability ... [or] ethnic origin'. ${ }^{144}$ However, it failed to provide what kind of measures must be adopted in order to include those belonging to racial or ethnic minorities.

The ICERD forbids racial discrimination in the enjoyment of the right to education, ${ }^{145}$ but provides no more than that. It is therefore difficult to see how it can benefit disabled children from racial or ethnic minorities. Turning to the CRC, the Convention refers to 'race' as well as 'disability' in its non-discrimination clause, ${ }^{146}$ but it has no explicit requirement to consider 
linguistic and cultural characteristics in the context of education. Neither the ICERD Committee nor the CRC Committee provides any indication as to how to attain this objective. International human rights law struggles when it comes to disabled children from racial or ethnic minorities. It appears that the intersection of age, race and disability contributes to diluting the problem. Such intersection leads to 'under-inclusion', which means that some grounds are overlooked as all the attention goes to one particular ground. ${ }^{147}$ Race receives the most attention, whereas disability remains in the background. The hypothesis to be further tested is whether the greater the intersection, the greater the difficulty in human rights protection.

While the main purpose of the present article has been to discuss particular groups of disabled people, there are of course some of them who can only invoke the CRPD. One of these groups is disabled people who are lesbian, gay, bisexual, transgender or intersex (LGBTI). Facing issues through the intersection of sexual orientation and disability, they experience a huge degree of prejudice. Disabled LGBTI people seem to fall between two stools because of being largely isolated from both the disability community and the LGBTI community. ${ }^{148}$

While there remains limited knowledge on the life-experience of disabled LGBTI people, ${ }^{149}$ evidence testifies the lack of awareness of disabled people among LGBTI persons and vice versa. An example is homosexuality that is not always tolerated by disabled people and particularly by medical personnel and caregivers. ${ }^{150}$ The problem is frequent for those who are intellectually disabled whose sexual orientation is often considered with contempt. ${ }^{151}$ Conversely, disability is sometimes not accepted by the LGBTI community, as it might be at odds with the 'body beautiful' culture and as cognitive difficulties can lead to negative stereotypes. ${ }^{152}$ A recurrent issue is the lack of physical access to the places usually occupied by LGBTI people, which marginalises those that are disabled. ${ }^{153}$ 
The question is: what does international human rights law have to offer disabled LGBTI people? These people have no human rights treaty that specifically applies to them other than the CRPD. The question then is whether the CRPD is able to protect them by itself. Although this Convention may do so in theory, it does not give them any explicit consideration. Its Preamble does not even mention sexual orientation. The Convention requires that States Parties take measures to "combat stereotypes, prejudices and harmful practices relating to persons with disabilities, including those based on sex and age' and that they guarantee the accessibility of 'facilities and services which are open or provided to the public'. ${ }^{154}$ There is yet to be any specification regarding those who are LGBTI.

A group of experts adopted the Yogyakarta Principles on the Application of International Human Rights Law in relation to Sexual Orientation and Gender Identity (Yogyakarta Principles), which clarifies human rights obligations towards LGBTI people. ${ }^{155}$ The Yogyakarta Principles provide that '[d]iscrimination based on sexual orientation or gender identity may be, and commonly is, compounded by discrimination on other grounds including ... disability'. ${ }^{156}$ However, they do not include other provisions on issues related to disability, and are non-binding, as their name indicates. A final possibility is to apply both the ICCPR and the ICESCR, the universal character of which may provide a way out for disabled LGBTI people. Their non-exhaustive list of discrimination grounds can serve as basis to ensure that these human rights treaties particularly benefit them.

International human rights law seems to be of limited use to protect disabled LGBTI. While no human rights treaty has been adopted for LBGTI people, the UN treaty bodies fail to make use of the Yogyakarta Principles. ${ }^{157}$ In its general comment on equality and nondiscrimination, the CRPD Committee recognised that disabled people 'can experience intersectional discrimination based on ... sexual orientation' and recommended that States Parties consult organisations which represent disabled people including those who are 
'lesbian, gay, bisexual, transgender or intersex'. ${ }^{158}$ Besides mentioning these people alongside other groups of disabled people, it has however not done anything to actively engage with them.

A similar exercise could be carried out for other groups of disabled people. These include older disabled people, indigenous disabled people as well as disabled people belonging to religious minorities amongst others. Especially worth noting is the Convention's limited consideration for older disabled people, especially since disability and old age are so much intertwined. ${ }^{159}$ The CRPD only mentions 'old age' twice, and it does not even do so in the Preamble. ${ }^{160}$ As initiatives to elaborate human rights treaties to protect older people, indigenous people or religious minorities have stalled, the affected groups of disabled people remain under the radar.

\section{Conclusion}

The present article explored the use of international human rights law with a view to protecting particular groups of disabled people. It examined what prejudices arise due to the intersection of disability and other grounds of discrimination, and considered what human rights protection is afforded to such groups of disabled people. The next step would be for all UN treaty bodies to draw more attention to disability. They should do so in concert that is, by jointly considering the question of intersectionality. This could be achieved, for instance, through the adoption of common general comments, as already done by the CEDAW and CRC Committee. ${ }^{161} \mathrm{~A}$ welcome fact is that the CRPD and CRC Committees have recently decided likewise to work on a common general comment on disabled children. ${ }^{162}$

The CRPD is amongst all human rights treaties the one that goes farthest regarding intersectionality. However, even though it contains some of the most advanced provisions in 
the field, it fails to consider equally the different groups of disabled people. This means then that these groups must rely on the provisions of other human rights treaties.

The present analysis has come up with different results regarding the protection of various groups of disabled people. First, disabled people belonging to racial or ethnic minorities are inadequately protected by international human rights law in which there is limited regard for the intersection of race and disability. Both the CRPD and the ICERD fall short, the former by not referring explicitly to race (leaving aside its Preamble) and the latter by not mentioning disability. Second, disabled women benefit from a high degree of human rights protection. There is a 'twin-track' approach in the CRPD, which even refers to 'multiple discrimination' in relation to disabled women. While the CEDAW does not refer to disability, the CEDAW Committee's general recommendations and concluding observations emphasise its genderrelated dimension. Third, disabled children have been given extensive consideration in international human rights law. The CRPD also gives them a prominent place through its 'twin-track' approach. The CRC contains several provisions on issues related to disability, including a full article on disabled children, which makes both human rights treaties highly relevant to them. Regarding other groups, it is more difficult to apply the CRPD along with other human rights treaties. Those who come within the remit of more than one group-specific human rights treaties other than the CRPD seem to fall through the net. Those who do not come within the remit of any such human rights treaty are even more disregarded.

The proliferation of human rights treaties leads to an unfortunate consequence. These human rights treaties are the direct result of a desire to better protect certain historically marginalised groups of people. When a new human rights treaty is being negotiated, special attention is given to particular groups within overall groups, and this attention varies according to their protection by earlier human rights treaties. The more these particular groups are acknowledged in the new human rights treaty, the more they will be able to lean on 
international human rights law. Those who are not acknowledged will continue to be ignored. This is reflected in the work of the UN treaty bodies, as can be seen from current practice. Disabled women and children have already been the subject of a lot of discussion since the CRPD was adopted. By contrast, disabled people belonging to ethnic minorities and disabled LGBTI people are rarely mentioned, if at all.

In summary, international human rights law does not equally benefit the different groups of disabled people. While applying human rights treaties consistently can help to achieve the best possible results, there remains disparity in the level of protection afforded to the various groups of disabled people. This can only be improved by increased awareness of the problem on the part of the UN treaty bodies themselves.

\footnotetext{
${ }^{1}$ Kimberley Crenshaw, 'Demarginalising the Intersection of Race and Sex: A Black Feminist Critique of Antidiscrimination Doctrine, Feminist Theory and Antiracist Politics', University of Chicago Legal Forum. Feminism in the Law: Theory, Practice and Criticism 4, no. 1 (1989): 139; Kimberley Crenshaw, 'Mapping the Margins: Intersectionality, Identity Politics, and Violence against Women of Color', Stanford Law Review 43, no. 6 (1991): 1241 .

${ }^{2}$ Iyiola Solanke, 'Putting Race and Gender Together: A New Approach to Intersectionality', Modern Law Review 72 , no. 5 (2009): 731 .

${ }^{3}$ Camilla Ida Ravnbøl, ‘The Human Rights of Minority Women: Romani Women’s Rights from a Perspective on International Human Rights Law and Politics', International Journal on Minority and Group Rights 17, no. 1 (2010): 1; Anastasia Vakulenko, 'Gender and International Human Rights Law: the Intersectionality Agenda', in Research Handbook on International Human Rights Law, ed. Sarah Joseph and Adam McBeth (Edward Elgar Publishing, 2010), 97; Nira Yuval-Davis, 'Intersectionality and Feminist Politics', European Journal of Women's Studies 13, no. 3 (2006): 193; Johanna Bond, 'International Intersectionality: A Theoretical and Pragmatic Exploration of Women's International Human Rights Violations', Emory Law Journal 52, no. 1 (2003): 71; Timo Makkonen, Multiple, Compound and Intersectional Discrimination: Bringing the Experiences of the Most Marginalized to the Fore (Turku: Institute for Human Rights, 2002).
} 
${ }^{4}$ Margaret Satterthwaite, 'Crossing Borders, Claiming Rights: Using Human Rights Law to Empower Women Migrant Workers', Yale Human Rights \& Development Law Journal 8, no. 1 (2005): 1.

${ }^{5}$ Ivona Truscan and Joanna Bourke-Martignoni, 'International Human Rights Law and Intersectional Discrimination', The Equal Rights Review 16, April (2016): 103.

${ }^{6}$ Johanne Bouchard and Patrice Meyer-Bisch, 'Intersecctionality and Interdependence of Human Rights: Same or Different?', The Equal Rights Review 16, April (2016): 186.

${ }^{7}$ Ben Smith, 'Intersectional Discrimination ans Substantive Equality: A Comparative and Theoretical Perspective', The Equal Rights Review 16, April (2016): 73.

${ }^{8}$ Pok Yin Chow, 'Has Intersectionality Reached its Limits? Intersectionality in the UN Human Rights Treaty Body Practice and the Issue of Ambivalence', Human Rights Law Review 19, no. 3 (2006): 453.

${ }^{9}$ Gerard Quinn and Theresia Degener, The Current Use and Future Potential of United Nations Human Rights Instruments in the Context of Disability (New York/Geneva: UN, 2002).

${ }^{10}$ Theresia Degener, 'Intersections between Disability, Race and Gender in Discrimination Law', in European Union Non-Discrimination Law and Intersectionality. Investigating the Triangle of Racial, Gender and Disability Discrimination, ed. Dagmar Schiek and Anna Lawson (Farnham: Ashgate, 2011), 29.

${ }^{11}$ Aart Hendriks, 'The UN Disability Convention and (Multiple) Discrimination: Should EU Non-Discrimination Law Be Modelled Accordingly?', in European Yearbook of Disability Law, ed. Lisa Waddington and Gerard Quinn (Antwerp: Intersentia, 2010), 7.

${ }^{12}$ Oddný Mjöll Arnardóttir, 'A Future of Multidimensional Disadvantage Equality?', in The UN Convention on the Rights of Persons with Disabilities. European and Scandinavian Perspectives, ed. Oddný Mjöll Arnardóttir and Gerard Quinn (London/Boston: Martinus Nijhoff Publishers, 2009), 41.

${ }^{13}$ Gauthier de Beco, 'Protecting the Invisible: An Intersectional Approach to International Human Rights Law', Human Rights Law Review 17, no. 4 (2017): 633.

${ }^{14}$ The present article opts for the term 'disabled people' and not 'people with disabilities'. The motivation for this choice is to reflect the idea that it is society that makes certain people disabled and that disability is not an inherent characteristic to them.

${ }^{15}$ For this reason, it is more appropriate to refer to the term of 'intersectionality' (rather than that of (intersectional discrimination'). 
${ }^{16}$ Rangita de Silva de Alwis, 'Mining the Intersections: Advancing the Rights of Women and Children with Disabilities within an Interrelated Web of Human Rights', Pacific Rim Law \& Policy Journal (18), no. 1 (2009): 295.

${ }^{17}$ Colin Clark, Dee Matthew and Vicky Burns, 'Power, Privilege and Justice: Intersectionality as Human Rights?', International Journal of Human Rights 22, no. 1 (2018): 115.

${ }^{18}$ John Tobin, 'Seeking to Persuade: A Constructive Approach to Human Rights Treaty Interpretation', Harvard Human Rights Journal 23, no. 1 (2010): 35.

${ }^{19}$ de Beco, 'Protecting the Invisible: An Intersectional Approach to International Human Rights Law', 657; Truscan and Bourke-Martignoni, 'International Human Rights Law and Intersectional Discrimination', 130.

${ }^{20}$ Crenshaw, 'Mapping the Margins: Intersectionality, Identity Politics, and Violence against Women of Color', 1298; Makkonen, Multiple, Compound and Intersectional Discrimination: Bringing the Experiences of the Most Marginalized to the Fore, 18-22.

${ }^{21} \mathrm{CRC}$, Articles 2 and 23.

${ }^{22}$ CRC Committee, General Comment No. 9: the Rights of Children with Disabilities, 27 February 2007, CRC/C/GC/9 (CRC Committee GC 9).

${ }^{23}$ CESCR Committee, General Comment No. 5: Persons with Disabilities, 9 December 1994, E/1995/22 (CESCR Committee GC 5).

${ }^{24}$ CESCR Committee GC 5, para. 5.

${ }^{25}$ CEDAW Committee, General Recommendation No. 18: Disabled Women, 30 January 1991, A/46/38 (CEDAW Committee GR 18).

${ }^{26}$ Kjersti Skarstad and Michael Ashley Stein, 'Mainstreaming Disability in the United Nations Treaty Bodies', Journal of Human Rights 17, no. 1 (2018): 7.

${ }^{27}$ See, inter alia, Arlene Kanter, The Development of Disability Rights under International Law. From Charity to Human Rights (London/New York: Routledge, 2015), 31-5; Gerard Quinn, 'Disability and Human Rights: A New Field in the United Nations', in International Protection of Human Rights: A Textbook, ed. Catarina Krause and Martin Scheinin (Turku: Institute for Human Rights, 2009), 250-2; Rosemary Kayess and Phillip French, 'Out of Darkness into Light? Introducing the Convention on the Rights of Persons with Disabilities', Human Rights Law Review 8, no. 1 (2008): 14-17.

${ }^{28} \mathrm{UN}$ General Assembly, Comprehensive and Integral International Convention on Protection and Promotion of the Rights and Dignity of Persons with Disabilities, 26 February 2002, A/RES/56/168. 
${ }^{29}$ See https://treaties.un.org/Pages/ViewDetails.aspx?src=IND\&mtdsg_no=IV-15\&chapter=4 (accessed 1 July 2019).

${ }^{30}$ CRPD, Article 5(2).

${ }^{31}$ CRPD Committee, General Comment No. 3 on Women and Girls with Disabilities, 25 November 2016, CRPD/C/GC/3 CRPD (CRPD Committee GC 3).

${ }^{32}$ CRPD Committee, General Comment on Equality and Non-discrimination, 9 March 2018, CRPD/C/GC/6, para. 73(o) (CRPD Committee GC 6).

${ }^{33}$ Deborah Stienstra, 'Race/Ethnicity and Disability Studies', in Routledge Handbook of Disability Studies, ed. Nick Watson, Alan Roulstone and Carol Thomas (London: Stienstra Routledge, 2012), 380-1.

${ }^{34}$ Lisa Schur, Douglas Kruse and Peter Blanck, People with Disabilities. Sidelined or Mainstreamed? (Cambridge: Cambridge University Press, 2013), 188-9; Faye Gary, 'Stigma: barrier to mental health care among ethnic minorities', Issues in Mental Health Nursing 26, no. 10 (2005): 989-90.

${ }^{35}$ Dan Goodley, Disability Studies. An Interdisciplinary Approach (London: SAGE Publications, 2011), 36.

${ }^{36}$ Nicola Burns, 'The Human Right to Health: Exploring Disability, Migration and Health', Disability \& Society 32, no. 10 (2017): 1467-9.

${ }^{37}$ Fundamental Rights Agency of the EU (FRA), Inequalities and Multiple Discrimination in Access to and Quality of Healthcare (Vienna: FRA, 2013), 55.

${ }^{38}$ Netherlands Institute for Human Rights, Oordeelnummer 2006-256, 21 December 2006, Ref. 2006-0029, para. 3(27), https://mensenrechten.nl/nl/oordeel/2006-256 (accessed 1 July 2019).

${ }^{39}$ Maria Pierce, 'Disabled Minority Ethnic People in Ireland: The Need for Recognition', in Re-thinking Identity. The Challenge of Diversity (Commissioned by the Joint Equality and Human Rights Forum), ed. Katherine $\begin{array}{llll}\text { Zappone, } & \text { June } & 2003, & 13 \text {, }\end{array}$ https://www.ihrec.ie/download/pdf/re_thinking_identity_the_challenge_of_diversity.pdf (accessed 1 July 2019).

${ }^{40} \mathrm{CRPD}$, Preambe(p).

${ }^{41}$ International Disability Alliance (IDA), Compilation of the CRPD Committee's Concluding Observations, http://www.internationaldisabilityalliance.org/resources/compilation-crpd-committee $\%$ E2\%80\%99s-concludingobservations (accessed 1 July 2019).

${ }^{42}$ CRPD Committee, Concluding observations on the report of the United Arab Emirates, 3 October 2016, CRPD/C/ARE/CO/1, para. 36 (a); CRPD Committee, Concluding observations on the report of Portugal, 18 
April 2016, CRPD/C/PRT/CO/1, para. 27; CRPD Committee, Concluding observations on the report of Germany, 13 May 2015, CRPD/C/DEU/CO/1, para. 40.

${ }^{43}$ CRPD Committee GC 6, para. 73(p).

${ }^{44} \mathrm{CMW}$ Committee/CRPD Committee, Addressing disabilities in large-scale movements of refugees and migrants, https://www.ohchr.org/Documents/HRBodies/CRPD/Statements/FINAL1004.docx (accessed 1 July 2019).

${ }^{45}$ CERD Committee, General Recommendation No. 25: Gender-related Dimensions of Racial Discrimination, 20 March 2000, HRI $\backslash G E N \backslash 1 \backslash$ Rev.6 at 214 (CEDAW Committee GR 25).

${ }^{46}$ Quinn and Degener, The Current Use and Future Potential of United Nations Human Rights Instruments in the Context of Disability, 234-5.

${ }^{47}$ CRPD, Article 27(1)(a).

${ }^{48}$ CRPD, Article 25(c).

${ }^{49}$ CRPD Committee, Marlon James Noble v Australia, 10 October 2016, CRPD/C/16/D/7/2012.

${ }^{50}$ World Conference against Racism Durban, Durban Declaration and Program of Action, 8 September 2001, A/CONF.189/12 (DDPA).

${ }^{51}$ DDPA, paras 14, 18, 31, 49, 79, 104, 172 and 212.

${ }^{52}$ DDPA, para. 57. The DDPA also invited the UN to elaborate 'an integral and comprehensive international convention to protect and promote the rights and dignity of disabled people' (DDPA, para. 180). This was to become the CRPD.

${ }^{53}$ Quinn and Degener, The Current Use and Future Potential of United Nations Human Rights Instruments in the Context of Disability, 75 and 131.

${ }^{54}$ de Silva de Alwis, 'Mining the Intersections: Advancing the Rights of Women and Children with Disabilities within an Interrelated Web of Human Rights', 29; FRA, Inequalities and Multiple Discrimination in Access to and Quality of Healthcare, 186-8; Carolyn Frohmader and Stephanie Ortoleva, The Sexual and Reproductive Rights of Women and Girls with Disabilities (Issues Paper commissioned by the ICPD International Conference $\begin{array}{lllll}\text { on } & \text { Human } & \text { Rights), } & \text { July } & \text { 2014, }\end{array}$ http://www.womenenabled.org/pdfs/issues_paper_srr_women_and_girls_with_disabilities_final.pdf (accessed 4 April 2019). 
${ }^{55}$ Leonard Cheshire Disability, Realising the Rights of Women and Girls with Disabilities, March 2014, section 3(4), https://www.leonardcheshire.org/sites/default/files/Women_and_girls_with_disabilities_0.pdf (accessed 1 July 2019).

${ }^{56}$ Mi Yeon Kim, 'Women with Disabilities', in Human Rights \& Disability Advocacy, ed. Maya Sabatello and Marianne Schulze (Philadelphia: Pennsylvania 2014), 115.

${ }^{57}$ Frohmader and Ortoleva, The Sexual and Reproductive Rights of Women and Girls with Disabilities, 4; Schur, Kruse and Blanck, People with Disabilities. Sidelined or Mainstreamed?, 177.

${ }^{58}$ World Health Organisation (WHO), Eliminating Forced, Coercive and Otherwise Involuntary Sterilization: An Interagency Statement by OHCHR, UN Women, UNAIDS, UNDP, UNFPA, UNICEF and WHO (Geneva: WHO, 2014), 5; World Health Organisation (WHO) and World Bank, World Report on Disability (Geneva: WHO, 2011), 78 .

${ }^{59}$ WHO and World Bank, World Report on Disability, 61.

${ }^{60}$ Lisa Alvares et al, Reproductive Health Justice for Women with Disabilities (Washington: Centre for Women Policy Studies, 2011), http://citeseerx.ist.psu.edu/viewdoc/download?doi=10.1.1.638.2433\&rep=rep1\&type=pdf (accessed 1 July 2019).

${ }^{61}$ CRPD, Article 6(1).

${ }^{62} \mathrm{CRPD}$, Articles 8, 16 and 25 .

${ }^{63}$ CRPD, Preamble(s).

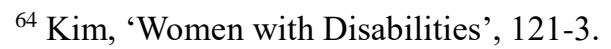

${ }^{65}$ CRPD Committee GC 3, para. 13.

${ }^{66}$ CRPD Committee GC 6, para. 36.

${ }^{67}$ Andrew Byrnes, 'Gender Challenges for International Human Rights', in Routledge Handbook of International Human Rights Law, ed. Scott Sheeran and Nigel Rodley (London/New York: Routledge, 2013), 617-19.

${ }^{68}$ UN General Assembly, Declaration on the Elimination of Violence against Women, 20 December 1993, A/RES/48/104 (DEVAW).

${ }^{69}$ CEDAW, Article 14(1).

${ }^{70}$ CRPD, Article 1.

${ }^{71}$ Fourth World Conference on Women, Beijing Declaration and Platform for Action, 5 September 1995, A/CONF.177/20 (BDfA).

${ }^{72}$ BPfA, para. 32. 
${ }^{73}$ CEDAW Committee, General Recommendation No. 26 on Women Migrant Workers, 5 December 2008, CEDAW/C/2009/WP.1/R; CEDAW Committee, General Recommendation No. 27 on Older Women and Protection of Their Human Rights, 16 December 2010, CEDAW/C/GC/27; CEDAW Committee GR 18.

${ }^{74}$ CEDAW Committee GR 18.

${ }^{75}$ CEDAW Committee GR 25, para. 12.

${ }^{76}$ CEDAW Committee, General Recommendation No. 28 on the Core Obligations of States parties under article 2, 16 December 2010, CEDAW /C/GC/28, para. 18; CEDAW Committee, General Recommendation No. 24 on women and health, 9 July 1999, A/54/38 at 5, para. 25 (CEDAW Committee GR 24).

${ }^{77}$ Skarstad and Stein, 'Mainstreaming Disability in the United Nations Treaty Bodies', 10-13. On the matter before the CRPD's adoption, see Quinn and Degener, The Current Use and Future Potential of United Nations Human Rights Instruments in the Context of Disability, 178-89.

${ }^{78}$ CEDAW Committee, AS v Hungary, 29 August 2006, CEDAW/C/36/D/4/2004; CEDAW Committee, Alyne da Silva Pimentel v Brazil, 10 August 2011, CEDAW/C/49/D/17/2008; CEDAW Committee, Kell v Canada, 26 April 2012, CEDAW/C/51/D/19/2008.

${ }^{79}$ CEDAW Committee, R.P.B. v the Philippines, 12 March 2014, CEDAW/C/57/D/34/2011, para. 8.7.

${ }^{80}$ CEDAW Committee GR 5, paras 19 and 31.

${ }^{81}$ CRPD, Article 16(1) and (2) (emphasis added).

${ }^{82}$ DEVAW, Article 4.

${ }^{83}$ CRPD, Article 23(1)(c).

${ }^{84}$ CRPD Committee GC 3, para. 45.

${ }^{85}$ Human Rights Committee, General comment No. 19: Article 23 (The family), 27 July 1990, para. 5.

${ }^{86}$ CRPD, Article 25(d).

87 CEDAW Committee, Concluding Observations on the Report of Australia, 30 July 2010, CEDAW/C/AUL/CO/7, para. 43.

${ }^{88}$ CESCR Committee GC 5, para. 31.

${ }^{89}$ CRPD, Article 23 (1)(b) and 25(a).

${ }^{90}$ CEDAW Committee GR 24, paras 25.

91 CEDAW Committee, Concluding Observations on the Report of Jamaica, 6 August 2012, CEDAW/C/JAM/CO/6-7, para. 36(a). 
${ }^{92}$ UNICEF, The State of the World's Children. Children with Disabilities (New York: UNICEF, 2013), 2, https://www.unicef.org/sowc2013/files/SWCR2013_ENG_Lo_res_24_Apr_2013.pdf (accessed 1 July 2019).

${ }^{93}$ Kanter, The Development of Disability Rights under International Law. From Charity to Human Rights, 225.

${ }^{94}$ UNICEF, The State of the World's Children. Children with Disabilities, 46-7.

${ }^{95}$ Arie Rimmerman, Family Policy and Disability (Cambridge, Cambridge University Press, 2015), 38.

${ }^{96}$ Inclusion Europe, Children's rights for all! Implementation of the United Nations Convention on the Rights of the Child for Children with Intellectual Disabilities (Brussels: Inclusion Europe, 2011), 14, http://www.eenet.org.uk/resources/docs/6130.pdf (accessed 1 July 2019).

${ }^{97}$ UNICEF, The State of the World's Children. Children with Disabilities, 27-8.

${ }^{98}$ UNICEF Innocenti Research Centre, Promoting the Rights of Children with Disabilities (New York: UNICEF, 2007), 17, https://www.un.org/esa/socdev/unyin/documents/children_disability_rights.pdf (accessed 1 July 2019).

${ }^{99}$ Inclusion International, Better Education for All When We are Included too. A Global Report (Brussels: $\begin{array}{lll}\text { Inclusion } & \text { International, } & \text { 2009), }\end{array}$ http://ii.gmalik.com/pdfs/Better_Education_for_All_Global_Report_October_2009.pdf (accessed 1 July 2019). ${ }^{100}$ Roger Slee, The Irregular School: Exclusion, Schooling and Inclusive Education (London/New York: Routledge, 2011), 71; Anastasia Liasidou, Inclusive Education, Politics and Policymaking (London Continuum, 2012), 175 .

${ }^{101}$ CRPD, Article 7(1).

${ }^{102}$ CRPD, Articles 8, 13, 16 and 23.

${ }^{103}$ CRPD Committee, General Comment No. 4 on the Right to Inclusive Education, 2 September 2016, CRPD/C/GC/4, para. 13 (CRPD Committee GC 4).

${ }^{104}$ CRPD Committee GC 6, para 38.

${ }^{105}$ Article 3, CRC. The three other ones are: non-discrimination (Article 2); the right to life, survival and development (Article 6) and; respect for the views of the child (Article 12).

${ }^{106}$ CRPD, Article 2(1).

${ }^{107}$ CRC, Article 23.

${ }^{108}$ CRPD, Article 7.

${ }^{109}$ Quinn, 'Disability and Human Rights: A New Field in the United Nations', 260. The reason it was eventually kept was to ensure that the four general principles of the CRC were included in the CRPD. While the principles 
of non-discrimination and the right to life, survival and development were already covered, those of the best interest of the child and the right of the child to be heard in all matters affecting her were not. See on this issue Gerison Landsdown, 'Children with Disabilities', in Human Rights \& Disability Advocacy, 99. The latter two general principles found their way into Article 6 of the CRPD.

${ }^{110} \mathrm{CRC}$, Article 23(2) and (3).

${ }^{111}$ de Silva de Alwis, 'Mining the Intersections: Advancing the Rights of Women and Children with Disabilities within an Interrelated Web of Human Rights’, 307.

${ }^{112}$ CRC Committee GC 9, para 2.

${ }^{113}$ CRC Committee, General comment No. 15 on the Right of the Child to the Enjoyment of the Highest Attainable Standard of Health (art. 24), 17 April 2013, CRC/C/GC/15, para. 8 (CRC Committee GC 15).

${ }^{114}$ CRC Committee, General comment No. 13 on the Right of the Child to Freedom from all Forms of Violence, 18 April 2011, CRC/C/GC/13, para. 60 (CRC Committee GC 13); CRC Committee, General Comment No. 17 on the Right of the Child to Rest, Leisure, Play, Recreational Activities, Cultural Life and the Arts (art. 31), 17 April 2013, CRC/C/GC/17, para. 16 (CRC Committee GC 17).

${ }^{115}$ Skarstad and Stein, 'Mainstreaming Disability in the United Nations Treaty Bodies', 16.

116 CEDAW Committee/CRC Committee, Joint General Recommendation/General Comment No. 31/18 on Harmful Practices, 4 November 2014, CEDAW/C/GC/31-CRC/C/GC/18, para. 8 (CEDAW Committee/CRC Committee JGR/GC 31/18).

${ }^{117}$ Skarstad and Stein, 'Mainstreaming Disability in the United Nations Treaty Bodies', 14-16. On the matter before the CRPD's adoption, see Quinn and Degener, The Current Use and Future Potential of United Nations Human Rights Instruments in the Context of Disability, 208-16.

${ }^{118}$ CRC Committee, General Comment No. 12: The Right of the Child to be Heard, 1 July 2009, CRC/C/GC/12, para. 75; CRC Committee GC 13, paras 9 and 54(b); CRC Committee GC 15, paras 5, 8 and 22; CRC Committee GC 17, paras 16, 57(f) and 58(b).

${ }^{119}$ UNICEF Innocenti Research Centre, Promoting the Rights of Children with Disabilities; UNICEF, The State of the World's Children.

${ }^{120}$ CRPD, Article 16(2) (emphasis added).

${ }^{121}$ CRC, Article 19(1).

${ }^{122}$ CRPD, Article 16(2); CRC, Article 19(2).

${ }^{123}$ CRC Committee GC 9, para. 43. 
${ }^{124}$ CESCR Committee GC 5, para. 32.

${ }^{125}$ CRPD Committee GC 6, para. 38.

${ }^{126}$ CRPD, Article 23(4); CRC, Article 9(1).

${ }^{127}$ CRC, Article 18(3).

${ }^{128}$ CRC Committee GC 9, para. 41.

${ }^{129}$ The CRC nonetheless makes room for alternative care, including 'placement in suitable institutions' (CRC, Article 20(3)), which has been interpreted as authorising institutionalisation. See on this issue Georgette Mulheir, 'Deinstitutionalization - A Human Rights Priority for Children with Disabilities', The Equal Rights Review 9, September (2012): 131. This interpretation is now contradicted by the right to independent living protected by Article 19 of the CRPD.

${ }^{130}$ CRC, Article 24(1).

${ }^{131} \mathrm{CRPD}$, Article 24(2)(b) and (d).

${ }^{132}$ Gauthier de Beco, 'The Right to Inclusive Education According to Article 24 of the UN Convention on the Rights of Persons with Disabilities: Background, Requirements and (Remaining) Questions', Netherlands Quarterly of Human Rights 32, no. 3 (2014): 273-4.

${ }^{133}$ The CRC Committee recognised that 'the measure in which the inclusion occurs, may vary' and that a 'continuum of services and program options must be maintained in circumstances where fully inclusive education is not feasible to achieve in the immediate future' (CRC Committee GC 9, para. 66).

${ }^{134}$ CRPD Committee GC 4, para. 12.

${ }^{135} \mathrm{CRC}$, Article 23(3).

${ }^{136}$ Anastasia Liasidou, 'Inclusive Education and Critical Pedagogy at the Intersections of Disability, Race, Gender and Class', Journal for Critical Education Policy Studies 10, no. 1 (2012): 173-4; Roberta Caldin, 'Inclusive Social Networks and Inclusive Schools for Disabled Children of Migrant Families', European Journal of Disability Research 8, no. 2 (2014): 107-8.

${ }^{137}$ One may argue that such children are just subject to racial discrimination, because they are referred to 'special schools' allegedly for a motive related to disability but, in reality, for one related to race only. However, this view has resulted in insufficient attention being paid to the way in which both discrimination grounds are intersecting. In any event, the fact is that certain statutory categories, such as the possession of emotional and behavioural difficulties, especially target children from racial or ethnic minorities. See for a discussion on this matter see 
Sally Tomlinson, 'Special Education and Minority Ethnic Young People in England. Continuing Issues', Discourse: Studies in the Culture and Politics of Education 37, no. 3 (2015): 1.

${ }^{138}$ Steve Strand and Geoff Lindsay, 'Ethnic Disproportionality in Special Education: Evidence from an English Population Study', Journal of Special Education 43, no. 3 (2009): 176-7; Tomlinson, 'Special Education and Minority Ethnic Young People in England. Continuing Issues', 8.

${ }^{139}$ Amnesty International (AI), A Tale of Two Schools: Segregating Romani into Special Education in Slovakia (London: AI, 2008), https://www.amnesty.org/fr/documents/EUR72/007/2008/en (accessed 1 July 2019).

${ }^{140}$ UNDP, Roma Education in Comparative Perspective. Analysis of the UNDP/World Bank/EC Regional Roma Survey (Bratislava: UNDP, 2011), 66-70, http://www.eurasia.undp.org/content/dam/rbec/docs/Roma-educationin-comparative-perspective.pdf (accessed 1 July 2019).

${ }^{141}$ European Court of Human Rights, DH and Others v Czech Republic, 13 November 2007; European Court of Human Rights, Sampanis and Others v Greece, 5 June 2008; European Court of Human Rights, Oř̌uš and Others v Croatia, 17 July 2008; European Court of Human Rights, Horváth and Kiss v Hungary, 29 January 2013.

${ }^{142}$ CRPD, Article 24.

${ }^{143}$ CRPD, Preambe(p).

${ }^{144}$ CRPD Committee GC 4, paras 12(e) and 13.

${ }^{145}$ ICERD, Article 5(c).

${ }^{146}$ CRPD, Article 2(1).

${ }^{147}$ Nicolas Bamforth, Maleiha Malik and Colm O'Cinneide, Discrimination Law: Theory and Context (London: Sweet and Maxwell, 2008), 533-53.

${ }^{148}$ William Leonard and Rosemary Mann, The Everyday Experience of Lesbian, Gay, Bisexual, Transgender and Intersex (LGBTI) People Living with Disability (Melbourne La Trobe University 2018), 7, https://www.glhv.org.au/sites/default/files/2018-07/GAFLA\%20Report\%20Final\%20Version.pdf (accessed 1 July 2019).

${ }^{149}$ Franco Dispenza et al, 'Subjective Health Among LGBT Persons Living With Disabilities: A Qualitative Content Analysis', Rehabilitation Psychology 61, no. 3 (2016), 252.

${ }^{150}$ Sonja Dudek, 'Institutionalized Queers: Homosexuality in Residential Facilities for People with Cognitive Disabilities', Disability Studies Quarterly 26, no. 2 (2006), http://dsq-sds.org/article/view/698/875 (accessed 1 July 2019). 
${ }^{151}$ Anthony Thompson et al, 'Prospects for Identity Formation for Lesbian, Gay, or Bisexual Persons with Developmental Disabilities', International Journal of Disability, Development and Education 48, no. 1 (2001), 59-60.

${ }^{152}$ Nathan Wilson et al, 'A Narrative Review of the Literature about People with Intellectual Disability Who Identify as Lesbian, Gay, Bisexual, Transgender, Intersex or Questioning', Journal of Intellectual Disabilities 22, no. 2 (2018), 187-8; Katherine Zappone, 'Conclusion: The Challenge of Diversity', in Re-thinking Identity. The

$\begin{array}{lll}\text { Challenge of } \quad \text { Diversity, } & 136,\end{array}$ https://www.ihrec.ie/download/pdf/re_thinking_identity_the_challenge_of_diversity.pdf (accessed 1 July 2019).

${ }^{153}$ Alan Martino, 'Cripping Sexualities: An Analytic Review of Theoretical and Empirical Writing on the Intersection of Disabilities and Sexualities', Sociology Compass 11, no. 5, 6-7; European Commission (EU), Tackling Multiple Discrimination: Practices, Policies and Laws (Brussels EU, 2007), 40.

${ }^{154}$ CRPD, Articles 8(1)(b) and 9(2)(b).

${ }^{155}$ Michael O'Flaherty, 'Sexual Orientation and Gender Identity', in International Human Rights Law, ed. D Moeckli et al (Oxford: Oxford University Press, $2^{\text {nd }}$ edn, 2014), 301.

${ }^{156}$ Yogyakarta Principles, Principle 2.

${ }^{157}$ Michael O’Flaherty, 'The Yogyakarta Principles at Ten', Nordic Journal of Human Rights 33, no. 4 (2015): 290.

${ }^{158}$ CRPD Committee GC 4, para. 13; CRPD Committee GC 6, para. 33.

${ }^{159}$ For the failed attempt to focus on indigenous disabled people in the CRPD, see Huhana Hickey, 'Indigenous People with Disabilities: the Missing Link', in Human Rights \& Disability Advocacy, 157.

${ }^{160}$ CRPD, Articles 25(b) and 28(2)(b).

${ }^{161}$ CEDAW Committee/CRC Committee JGR/GC 31/18.

162 The author is grateful to the CRPD Committee for having provided him with this information. 